2015

\title{
Caddo Archaeological Sites on San Pedro Creek in Houston County, Texas: San Pedro de los Nabedaches
}

Timothy K. Perttula

Heritage Research Center, Stephen F. Austin State University

Follow this and additional works at: https://scholarworks.sfasu.edu/ita

Part of the American Material Culture Commons, Archaeological Anthropology Commons, Environmental Studies Commons, Other American Studies Commons, Other Arts and Humanities Commons, Other History of Art, Architecture, and Archaeology Commons, and the United States History Commons

Tell us how this article helped you.

This Article is brought to you for free and open access by the Center for Regional Heritage Research at SFA ScholarWorks. It has been accepted for inclusion in Index of Texas Archaeology: Open Access Gray Literature from the Lone Star State by an authorized editor of SFA ScholarWorks. For more information, please contact cdsscholarworks@sfasu.edu. 
Caddo Archaeological Sites on San Pedro Creek in Houston County, Texas: San Pedro de los Nabedaches

\section{Creative Commons License}

\section{(c) (1) \&}

This work is licensed under a Creative Commons Attribution-NonCommercial 4.0 International License 


\title{
Caddo Archaeological Sites on San Pedro Creek in Houston County, Texas: San Pedro de los Nabedaches
}

\author{
Timothy K. Perttula
}

\section{INTRODUCTION}

The Nabedache Caddo that lived on San Pedro Creek in Houston County in the East Texas Pineywoods (Figure 1) were a prominent nation during the early years of European contact, from ca. A.D. 1687-1730. Their villages, hamlets, and farmsteads sat astride an aboriginal trail that came to be known as El Camino Real de los Tejas, and thus their community was a principal gateway to Europeans and other Native American tribes who came from the west in Spanish Texas to meet with the Tejas or Hasinai Caddo peoples. The first Spanish mission in East Texas was established amidst the Nabedache Caddo community (Weddle 2012:2).

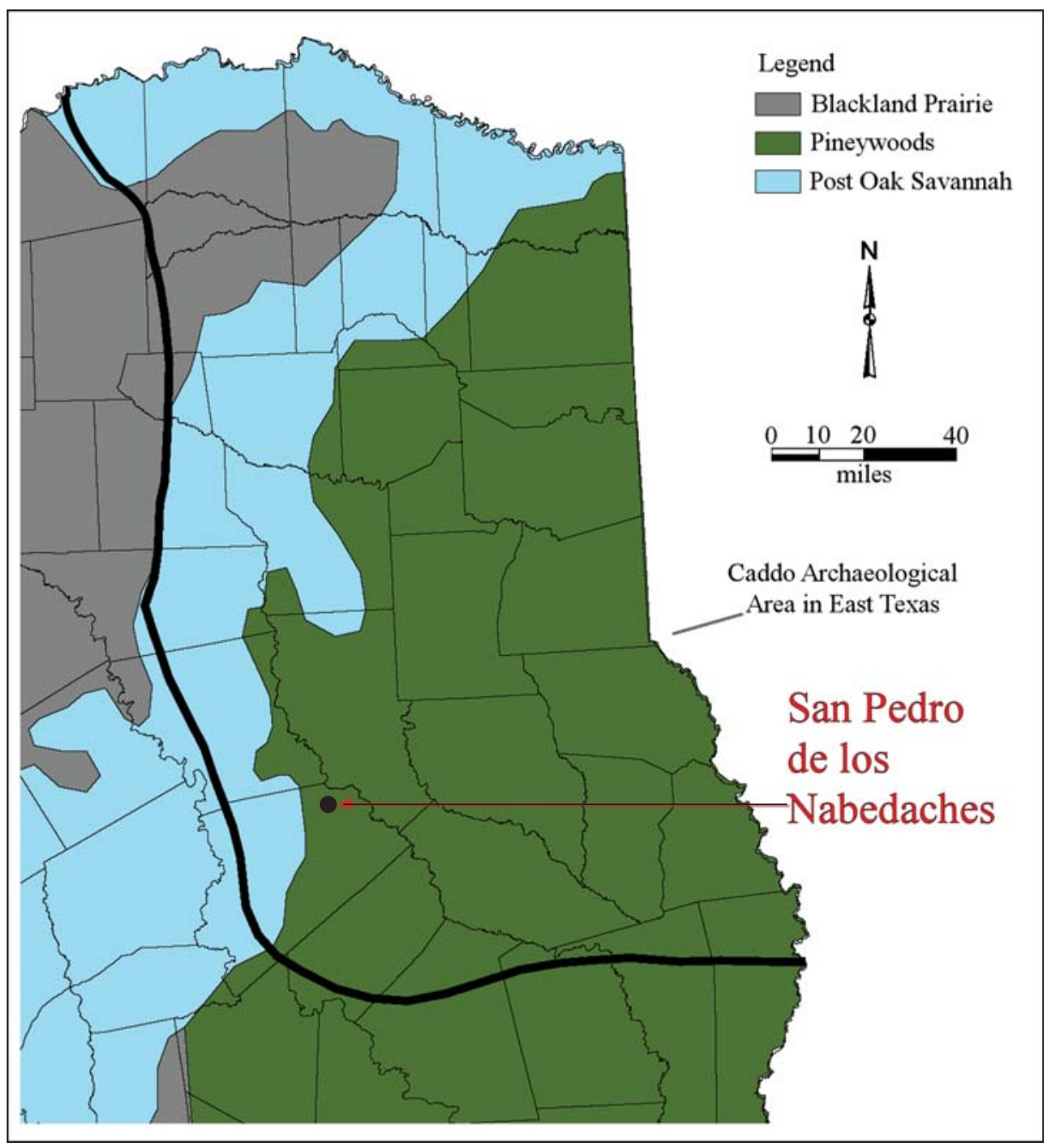

Figure 1. The location of San Pedro Creek sites in East Texas: San Pedro de los Nabedaches. 
The archaeology of the Nabedache Caddo, or that of their pre-A.D. 1542 ancestors, is not well understood, primarily because of the dearth of intensive investigations at a range of Nabedache Caddo sites. Work that has been completed, primarily on sites at Mission Tejas State Park, have included surveys and limited test excavations at a few sites (see summary in Perttula and Nelson 2006:27-29) that have Caddo material culture remains (sherds from ceramic vessels, chipped stone tools, etc.) and European trade goods, including glass beads, gunflints, lead balls and sprue, an iron hoe, an iron rowel, a possible strike-a-light, an iron gun cock, trigger plate, butt plate finial, and gun barrel fragments, iron cast iron kettle fragments, iron knife fragments, wrought iron nails, brass tinklers, and Spanish majolica sherds (Perttula and Nelson 2006:181-185). In this article, I discuss the archaeological material culture remains from several Nabedache Caddo sites along San Pedro Creek that are in the collections of the Texas Archeological Research Laboratory at The University of Texas at Austin.

\section{HISTORICAL CONTEXT}

When the Caddo Indian peoples living in East Texas were first visited by Europeans in 1542, the remnants of the De Soto entrada (Bruseth and Kenmotsu 1993) described to chroniclers that the Caddo in East Texas lived in scattered but dispersed settlements with abundant food reserves of corn. The entrada moved along pre-existing east-west and north-south Caddo trails through East Texas, and from Hasinai Caddo groups in the Neches-Angelina River basins to Cadohadacho groups on the Red River (Figure 2). The east-west aboriginal trail in most particulars became subsumed within the later East Texas portions of the El Camino Real de los Tejas first established by the Spanish in the late 17th century (Weddle 2012:1-28; Williams 2007:Figure 8).

Archaeological investigations carried out in East Texas since the early 20th century confirm that Caddo communities were widely dispersed throughout all of the major and minor river valleys of the region. The most intensive settlement of the region may have been after ca. A.D. 1400, especially in the Neches-Angelina River basin (Story 1995). By the mid-1600s, the Hasinai Caddo peoples of East Texas were referred to by the Spanish as the "Great Kingdom of the Tejas" because they were considered to be a populous and wellgoverned people.

When Europeans began to venture into East Texas in the 1680s and 1690s, the territory of the various Hasinai Caddo tribes became well understood (see Berlandier 1969; Jackson 1999; R. H. Jackson 2004). The area known to have been occupied by the Caddo in the late 17th century was also called "Tejas" by the Spanish, while the French called the Caddo in this area the "Cenis" (Figure 3). The Nabedache Caddo villages on San Pedro Creek were the principal entranceway to the lands of the Hasinai Caddo tribes that lived in the Neches and Angelina River basins, and one of the routes of the Camino Real-El Camino Real de los Tejas-came to and through this place from the late 17th to the early 19th century (Corbin 1991; Cunningham 2006). According to Weddle (2012:2):

The Spanish first focused their interest on the Nabedaches with a short-lived mission in 1690, for it was among the Nabedaches that La Salle's remnant had appeared, just a few years previously, as it sought a path to the Mississippi. Thus, the amorphous Camino Real first directed itself toward the Nabedache village, situated between the Trinity and Neches Rivers. Beginning in 1716, missionary endeavors would be directed at other tribes of the Caddoan [sic] confederacies as well.

In historic times, the archaeology of the Hasinai Caddo groups is associated with the Allen phase (ca. A.D. 1650-early 1800s). "The Allen phase is believed to have developed out of the Frankston phase [ca. A.D. 1400-1650], and more importantly, to have shared the same form of organization, kinds of inter-group interaction, and settlement patterns" (Story and Creel 1982:34). The groups who during the Allen phase occupied the Neches (the Rio aux Cenis) and Angelina river basins were direct ancestors of the Hasinai tribes (see Figure 3) who were living in or near the Spanish missions that had been periodically established 


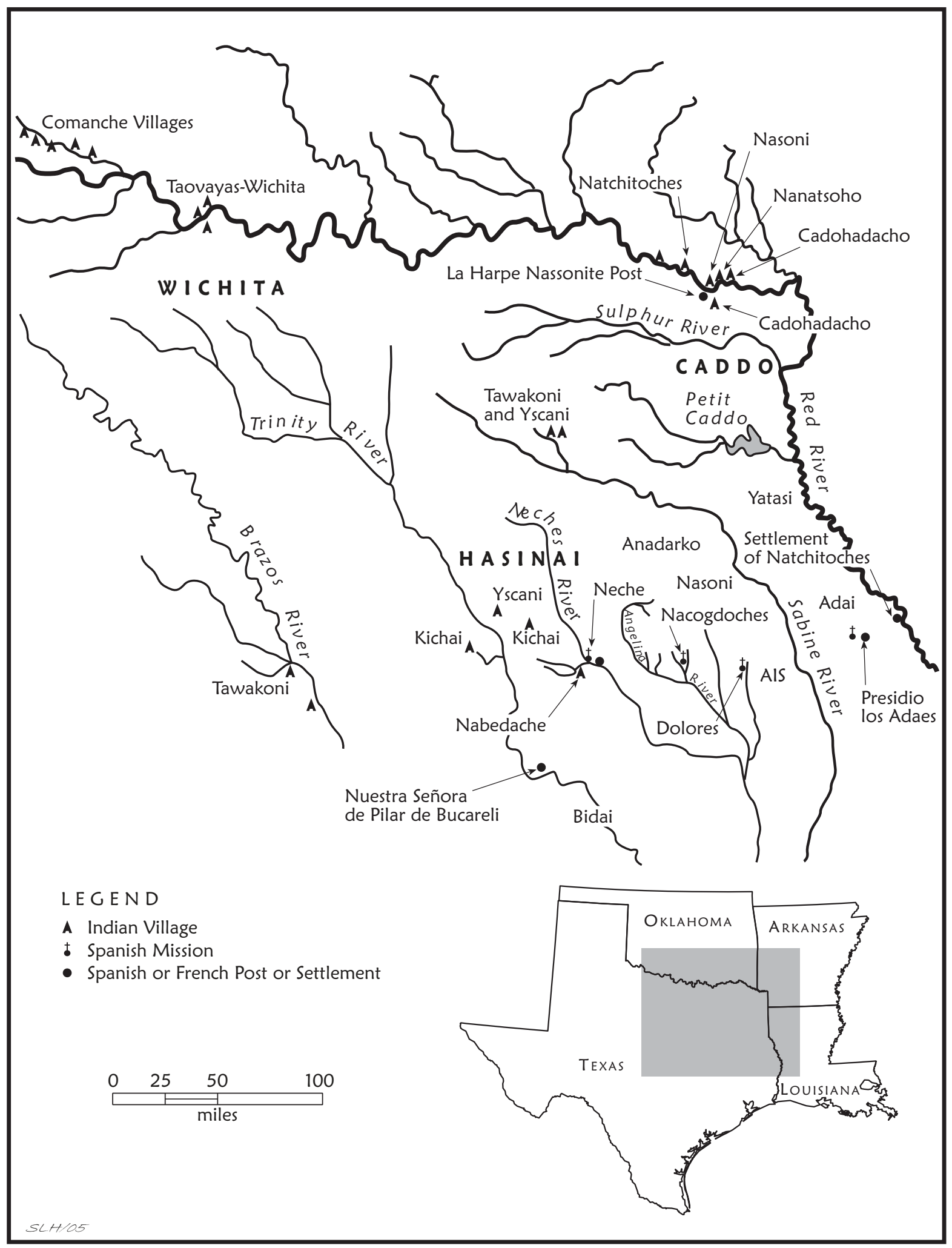

Figure 2. The distribution of Caddo groups in East Texas, as well as 17th and 18th century French and Spanish missions and settlements. 


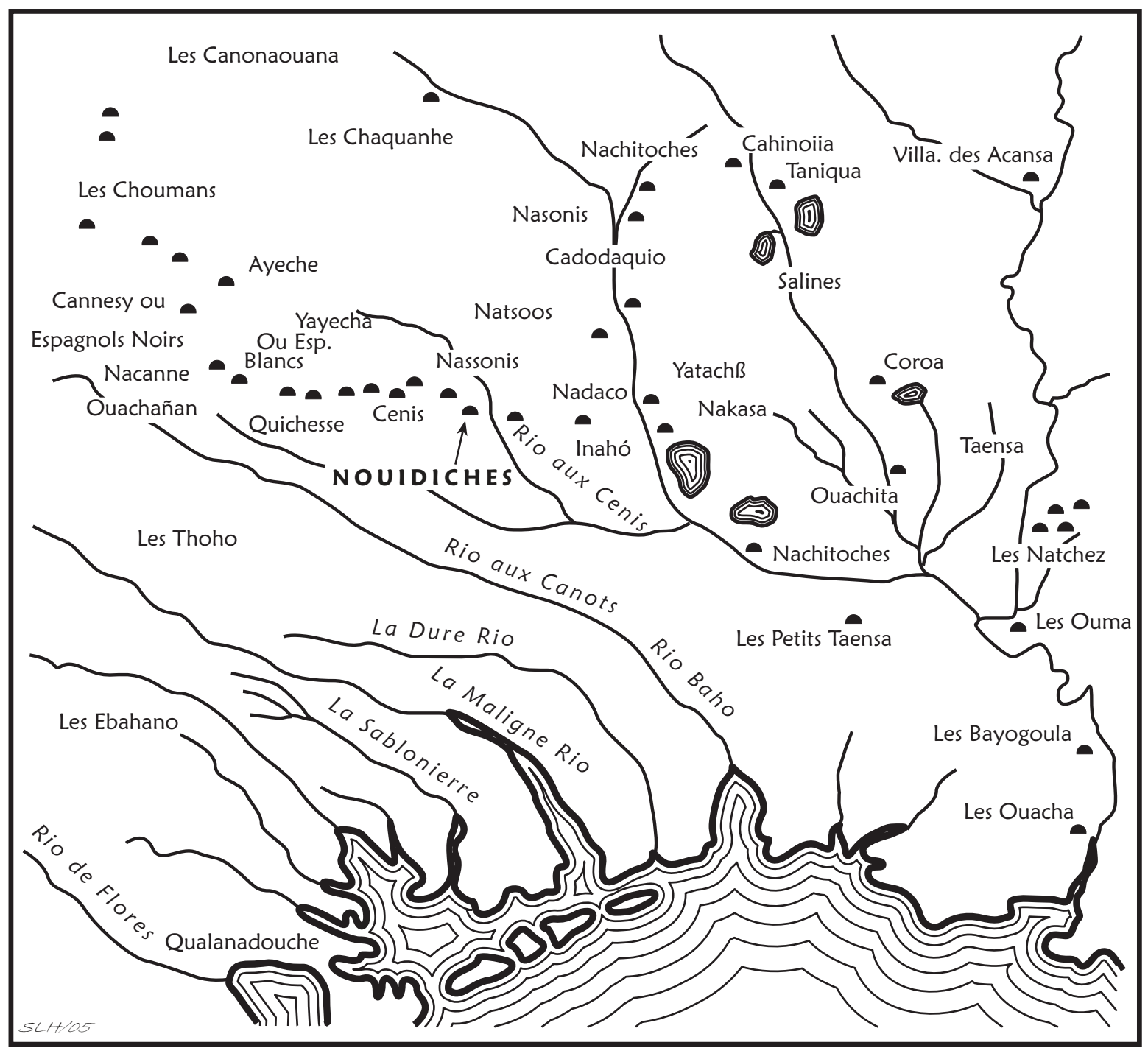

Figure 3. Redrawn version of Guillaume Delisle Map, 1702, "Carte de Canada et du Mississippi." The Nouidiches or Nabedache lived on San Pedro Creek near its confluence with the Neches River.

and maintained in the region between ca. 1690-1731, and they continued to live there until the 1830s (see Jackson 1999:Plate 98).

Story and Creel (1982:32) have suggested that the Allen phase populations were organized in a "weakly hierarchical structure" analogous to the Hasinai confederacy (see Swanton 1942). Allen phase components are found in the Neches and Angelina River basins in Cherokee, Anderson, Houston, Rusk, and Nacogdoches counties (Erickson and Corbin 1996; Middlebrook 2007; Perttula and Nelson 2006; Story 1982, 1995). These Historic Caddo sites contain small amounts of European trade goods found in village contexts, along with a variety of decorated and plain Caddo ceramic wares, triangular and unstemmed arrow points, elbow pipes, ground stone tools, and bone tools. Most Allen phase sites were apparently occupied for only short periods of time, perhaps an average of 20 to 40 years (Good 1982:67-69).

Allen phase Caddo communities were apparently composed of many farmsteads spread out over a considerable distance. In 1687, in the community of Nabedache Caddo on San Pedro Creek in Houston County (see Figure 3), Henri Joutel noted that: 
we took the path to the village where the Indians conducted us to the chief's hut which was a long league's distance from the entrance to the village. On the way, we passed several huts that were grouped in hamlets; there were seven or eight of them, each with twelve to fifteen huts together with space between each other and fields around the huts (Foster 1998:206).

Individual Hasinai Caddo families lived in their farmsteads, and a number of farmsteads were organized into rancherias spread out over about 15-30 leagues (ca. 39-78 miles) of stream valleys and arable lands. Each rancheria was separated from the others by unoccupied lands and hunting territory (Foster 1998:208).

The Spanish were determined to have effective control of the East Texas lands, thus minimizing the French influence, and bring missions to the Caddo peoples (R. H. Jackson 2005:22-23, 26; Wade 2008:107113). Between 1690 and 1719, the Spanish established a number of missions among the Hasinai Caddo in East Texas, with most of them situated in the middle of Caddo communities and along what became the Camino Real de los Tejas (Figures 4-6). Despite the efforts of the missionaries, the Caddo refused to congregate in the vicinity of the missions, and no Caddo peoples were converted to Christianity; baptisms "were administered to [Caddo] people who had died or were dying, half of whom were children" (Wade 2008:112).

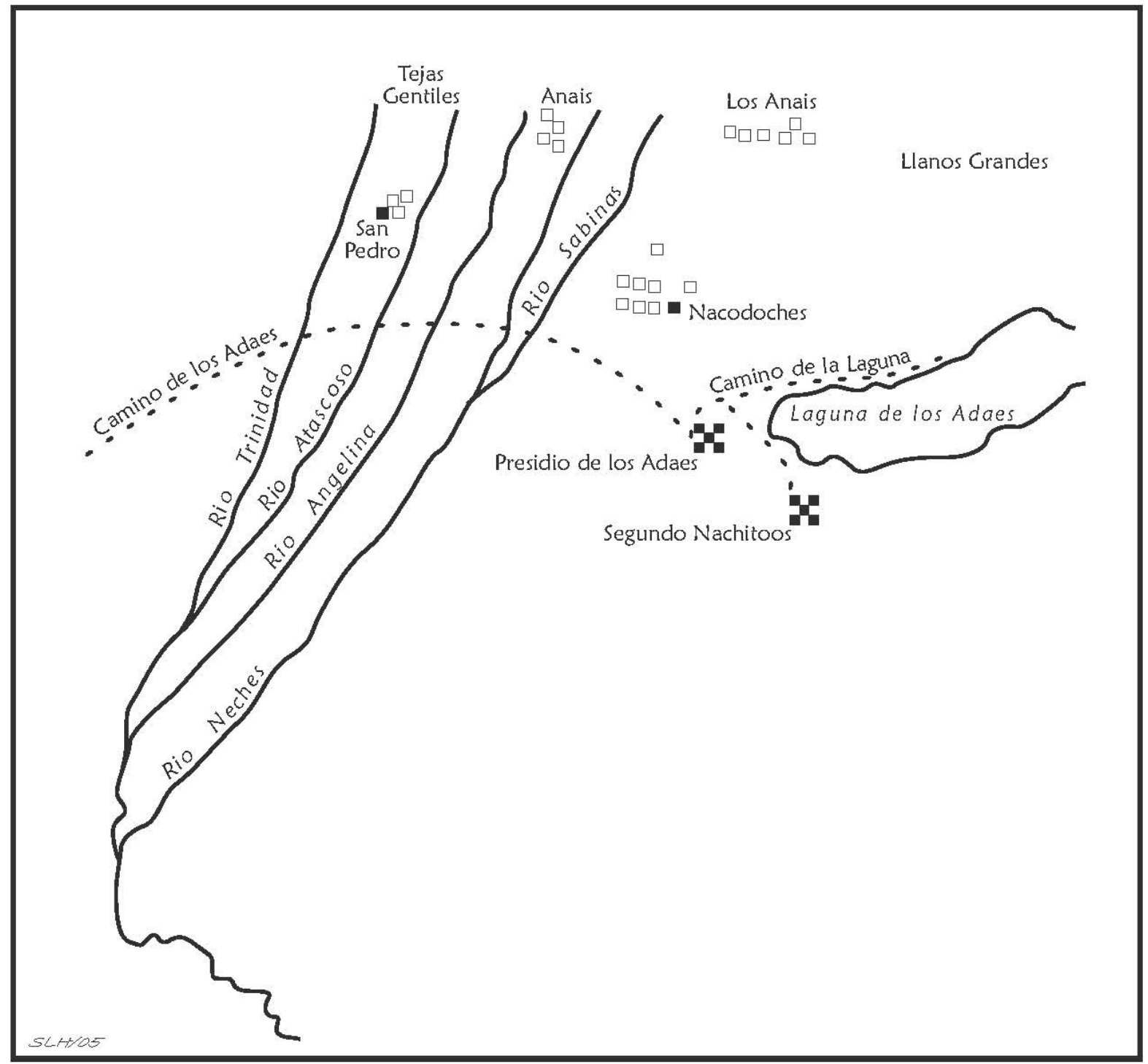

Figure 4. Redrawn 1740 map of East Texas, Sandoval and Franquis map (Jackson 1999:Plate 34 and Figure 5). 


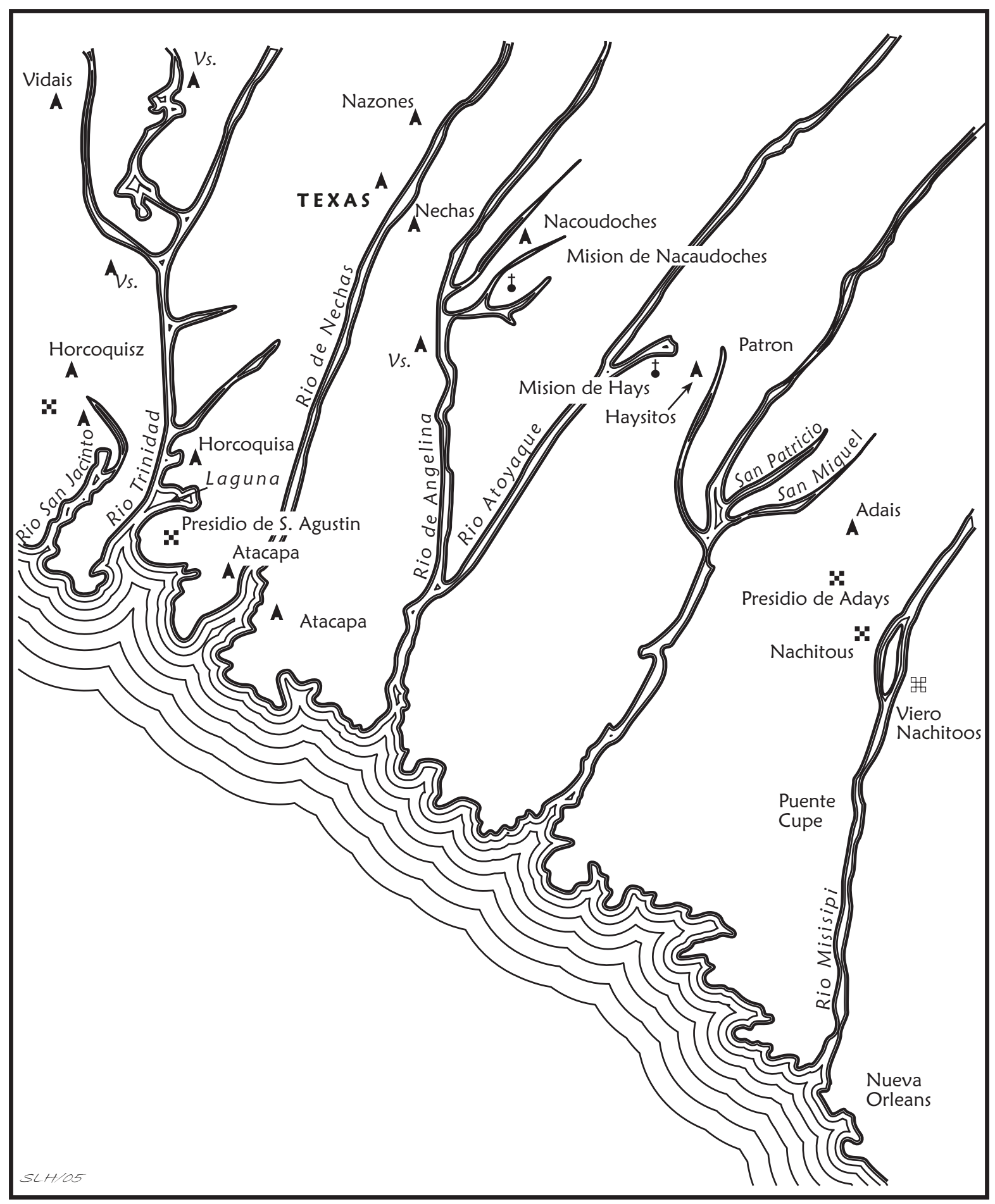

Figure 5.Redrawn version of 1757 map by Miranda, "Parte de la Provyncya De Texas"(Jackson 1999:Plate 35).

One of these missions was Mission San Francisco de los Tejas (1690-1693) on San Pedro Creek a few miles from its confluence with the Neches River. This mission has never been found, but then again there has not been a concerted archaeological, archival, and historical investigation of the San Pedro Creek valley to identify the site and the surrounding Nabedache Caddo community. 


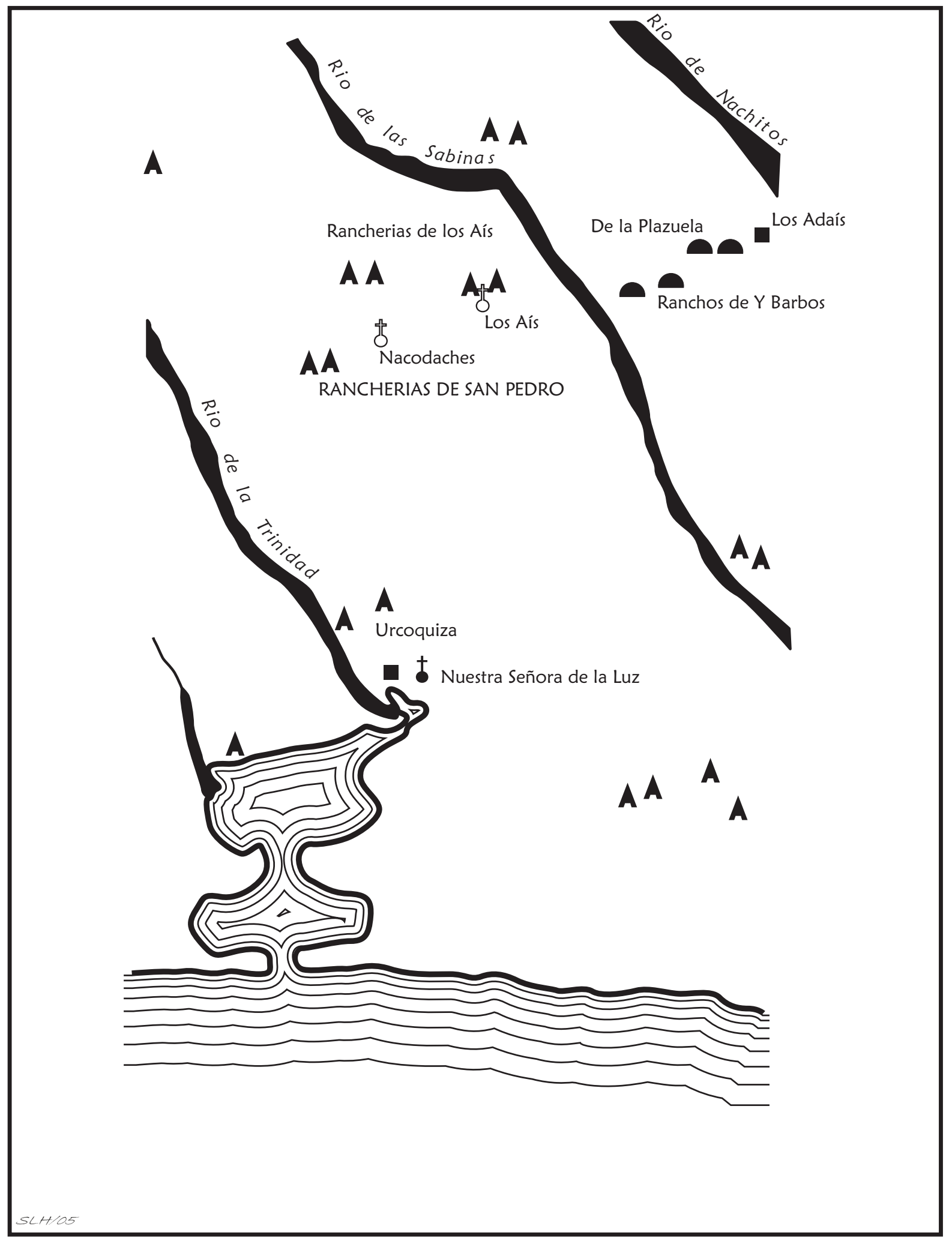

Figure 6. Redrawn version of 1771 map by Jose de Urrutia, "Map de toda Frontera de los dominios del rey en la America septentrional” (R. H. Jackson 2005:Map 10a). 
Delisle's map of 1702 (see Figure 3) shows that the westernmost Caddo groups (the Cenis) were living on and near the Neches River, west of the Neches on San Pedro Creek. In the 1720s-1750s, the Hainai Caddo lived to the east on the Angelina River (see Figure 4), while the Nadaco and Nasoni were in communities to the north and west - apparently above the Camino Real - and a series of Cenis or Hasinai communities were along the western boundaries of their territory. The San Pedro or Nabedache Caddo were living east of the Trinity River and west of the Neches River (see Figure 4). At these times, Spanish missionaries were living in the midst of certain Caddo peoples at Mission Nuestra Senora de los Nacogdoches and Mission Nuestra Senora de Ais (see Figure 5). A 1771 map by Jose de Urrutia shows Caddo groups living north and west of these two missions (see Figure 6). The missions at Nacogdoches and Ais were abandoned in 1772 and 1773 , respectively.

Because of the regular outbreaks of epidemics among the East Texas Caddo, especially outbreaks at the Spanish settlement of Nacogdoches in the late 1770s and early 1780s, Caddo populations declined precipitously through the colonial era (Table 1). Caddo groups moved their villages, or coalesced into one village for protection. The Hasinai Caddo groups - the Nacogdoche, Hainai, the Hasinai, the Nadaco, Ais, and the Nabedache-remained in their East Texas homelands, living in the early 1800s outside of the Spanish settlements of Nacogdoches, west to the Neches River, and apparently north of the El Camino Real (Figure 7). Between about 1836 and 1839, the Hasinai tribes had all been forcibly pushed out of East Texas, and they either moved to Indian Territory, or farther west in Texas (in the upper Trinity and Brazos River basins, see Neighbours 1973, 1975).

Table 1. East Texas Caddo Populations through the Colonial Era.

\begin{tabular}{|c|c|c|c|}
\hline Year & Source & Warriors* & Population \\
\hline \multicolumn{4}{|l|}{ Hasinai } \\
\hline 1699 & Pierre Talon & $600-700$ & $2400-2800$ \\
\hline 1716 & Ramon & - & $4000-5000$ \\
\hline 1721 & Aguayo & - & ca. 1378 \\
\hline 1779 & De Mezieres & 135 & 540 \\
\hline 1783 & Morfi & $380(?)$ & 1520 \\
\hline 1805 & Sibley & 200 & 800 \\
\hline $1818-20$ & Cincinnati Gazette & 150 & 650 \\
\hline 1820 & Padilla & - & 1450 \\
\hline 1828 & Teran & 23 & 92 \\
\hline 1828 & Berlandier & $30-40$ & $120-160$ \\
\hline 1834 & Almonte & - & 400 \\
\hline 1836 & Republic of Texas & - & 200 \\
\hline \multicolumn{4}{|l|}{ Hainai } \\
\hline 1783 & Morfi & 80 & 320 \\
\hline 1798 & Davenport & 60 & 240 \\
\hline 1809 & Salcedo & 60 & 240 \\
\hline 1828 & Berlandier & 10 & 40 \\
\hline \multicolumn{4}{|c|}{ Nabedache } \\
\hline 1779 & De Mezieres & 40 & 160 \\
\hline 1783 & Morfi & 40 & 160 \\
\hline 1798 & Davenport & 80 & 320 \\
\hline 1819 & Padilla & - & 500 \\
\hline
\end{tabular}


Table 1. East Texas Caddo Populations through the Colonial Era, cont.

\begin{tabular}{|c|c|c|c|}
\hline Year & Source & Warriors* & Population \\
\hline 1828 & Teran & 15 & 60 \\
\hline 1828 & Berlandier & 80 & 400 \\
\hline \multicolumn{4}{|c|}{ Nacogdoche } \\
\hline 1783 & Morfi & 300 & 1200 \\
\hline 1798 & Davenport & $50 * *$ & 200 \\
\hline 1809 & Salcedo & 50 & 200 \\
\hline 1828 & Berlandier & 50 & 200 \\
\hline \multicolumn{4}{|l|}{ Nadaco } \\
\hline 1798 & Davenport & 100 & 400 \\
\hline 1809 & Salcedo & 100 & 400 \\
\hline 1828 & Teran/Sanchez & 29 & 116 \\
\hline 1828 & Berlandier & 30 & 150 \\
\hline \multicolumn{4}{|l|}{ Ais } \\
\hline 1716 & French traders & - & 320 \\
\hline 1779 & De Mezieres & 20 & 80 \\
\hline 1805 & Sibley & - & 25 \\
\hline $1818-20$ & Cincinnati Gazette & - & 50 \\
\hline 1820 & Padilla & - & 300 \\
\hline 1828 & Muckleroy/Teran & - & 640 \\
\hline 1828 & Berlandier & - & 300 \\
\hline
\end{tabular}

*one warrior is assumed to equate to four members of a family, but it is likely that this underestimates population sizes; some sources estimated five members to a family or five people per warrior. This table is based in part on the work of Swanton (1942:22-23).

**Nacogdoche and Ais groups

As previously mentioned, Mission San Francisco de los Tejas (1690-1693) was also situated on San Pedro Creek (Figure 8), apparently astride the Camino de los Tejas (labeled "Ancienne route de Bexar a Nacogdoches"). This mission was established "in the middle" of the Nabedache Caddo village along San Pedro Creek (Bolton 1987:41), perhaps about 2 leagues (ca. 5.2 miles) from the Neches River; Weddle (2012:45) suggests it was actually 4 leagues from the mission site to the Neches River along El Camino de los Tejas.

\section{KNOWN ARCHAEOLOGICAL SITES}

Archaeological evidence of Nabedache Caddo settlements that were occupied contemporaneously with the use of the Camino Real are known along San Pedro Creek, from near the headwaters to the confluence of San Pedro Creek and the Neches River (Erickson and Corbin 1996; Perttula 2004; Perttula and Nelson 2006, 2007; Perttula et al. 2011). These include 41HO6 (with a Spanish cannon or breech block discovered there, see Newell and Krieger 1949:13-14; Woldert 1935), 41HO64, 41HO65, 41HO66, and 41HO67 on the north side of San Pedro Creek (Newell and Krieger 1949; Perttula 2004; Perttula et al. 2011) and across from Mission Tejas State Park; the Plev Cutler site (41HO1) on a terrace at the confluence of the Neches River and San Pedro Creek; and 41HO91, 41HO122, Nabedache Blanco (41HO211), and Nabedache Azul (41HO214) within Mission Tejas State Park (Erickson and Corbin 1996; Perttula and Nelson 2006, 2007a, 2007b). 


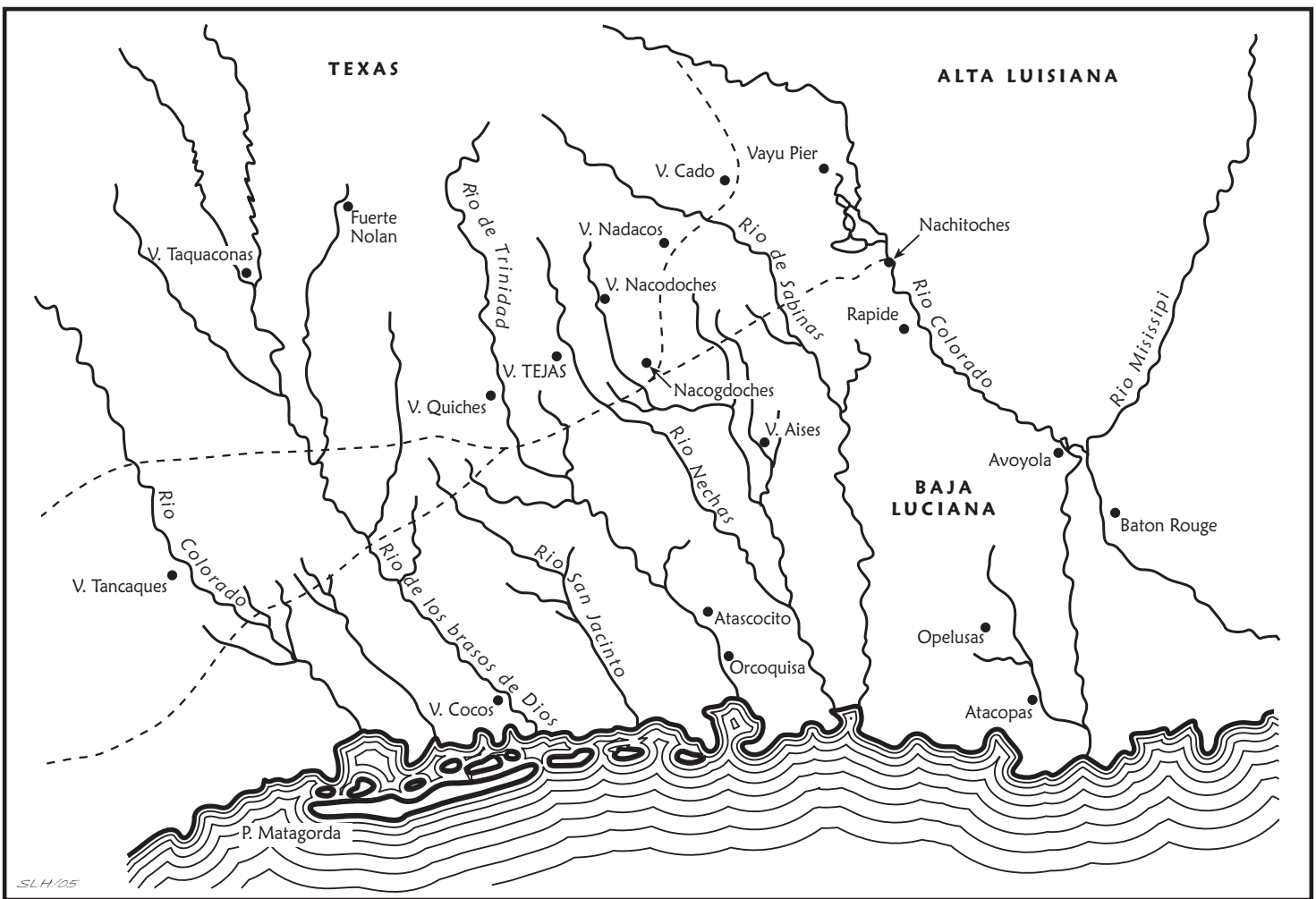

Figure 7. Redrawn version of Father Puelles 1801 map, "provincia de Texas en Luisiana."

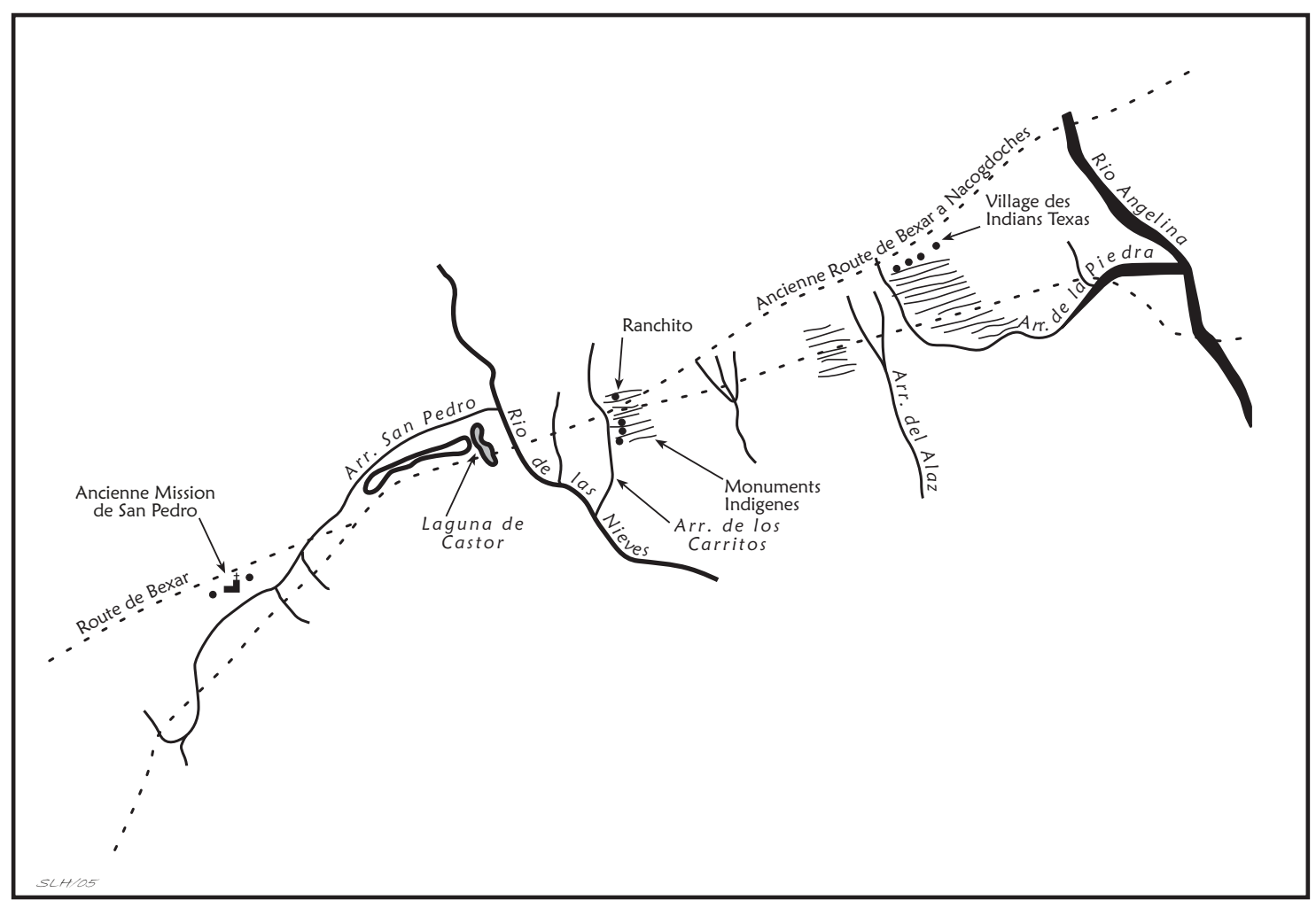

Figure 8. Redrawn version of ca. 1806 Juan Pedro Walker map of the area from San Pedro Creek on the west to the Angelina River (see McGraw et al. 1991:Figure 26). 
The collections discussed here were gathered by Alex D. Krieger in April 1944 during the course of a geological and archaeological reconnaissance of the lower valley of San Pedro Creek (Figure 9). Krieger noted that "on the north bank of San Pedro Creek, about 3 miles above (and west of) the confluence with the Neches, we located a large site with many glass beads and iron fragments. A small cannon, now at the San Jacinto Memorial near Houston, Texas, was plowed up here about 1933. This place is... in a logical place for settlement and probably agreeable with Bolton's location of Nabedache" (Newell and Krieger 1949:13-14; see also Bolton 1908). In total, seven archaeological sites were located during the Krieger reconnaissance of plowed fields along San Pedro Creek, most of them on land owned by George A. Moore of Augusta, Texas: George A. Moore 1a (41HO6), 1b (41HO64), 1c (41HO65, with a catlinite pipe, see Perttula [2004:Figures 9-10]), 2 (41HO66), and 3 (41HO67), as well as Sites 4 (41HO68) and 5 (41HO69) in different parts of the valley (Figure 9).

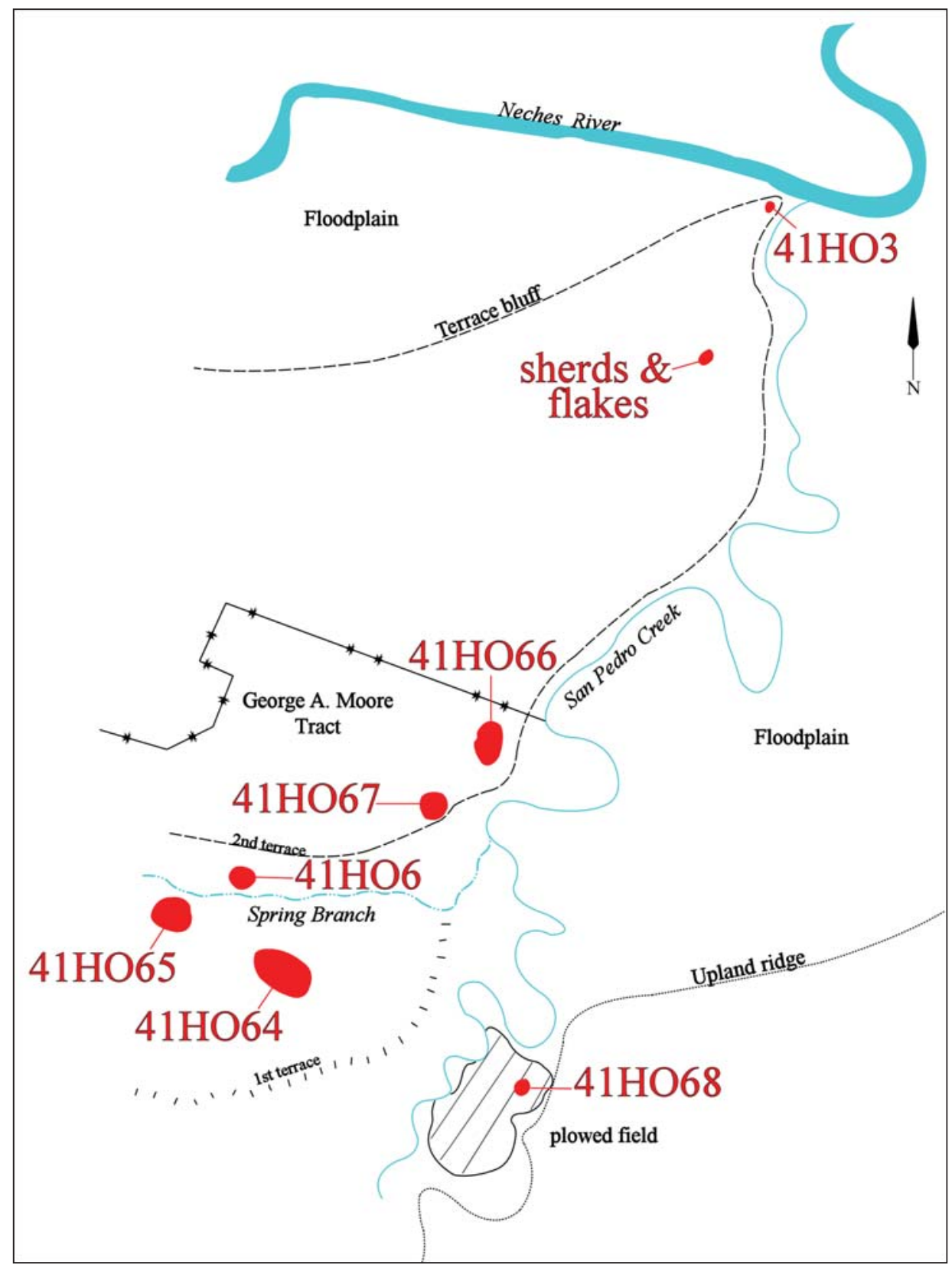

Figure 9. Redrawn from Krieger's 1944 map of the lower valley of San Pedro Creek showing the location of archaeological sites. 


\section{$41 \mathrm{HO64}$}

The site with the reputed cannon-41HO6-was said by Mr. Moore to have been in a plowed field north of a small draw (a spring-fed tributary to San Pedro Creek) (see Figure 9); Woldert (1935) reported that the cannon was found at a depth of ca. $25 \mathrm{~cm}$ while Mr. Moore was plowing the field. Weddle (2012:47) suggests that this object is actually "the breech block of a small-bore artillery piece, such as a swivel gun." Whether this breech block, at the San Jacinto Museum of History is the same piece of artillery mentioned by Moore to Woldert or Krieger is an open debate and probably not easily resolved. The catalogue information for the breech block at the San Jacinto Museum of History indicates that it was found by George A. Moore in 1923 (Weddle 2012:46); Newell and Krieger (1949:14) have the discovery about 1933.

Not far to the south, but south of the draw (see Figure 9) and on the first alluvial terrace or alluvial fan, Moore had plowed up 7-8 Caddo Indian burials that had many glass beads found in association. Perttula (2004) has discussed some of the archaeological findings from 41HO64 and nearby site 41HO65, based on the documentation of the Jackie Lively (and George A. Moore) collection from these sites. An assemblage of 7646 beads has been documented from 41HO64 (see Perttula 2004:93 and Table 1), and these are consistent with ca. A.D. 1690-1730 beads found in other East Texas Caddo sites.

During the Krieger 1944 reconnaissance two glass beads were collected from the plowed field. One is a small (2.8 $\mathrm{mm}$ in diameter) opaque round white bead (IIa13 in the Kidd and Kidd [1970] classification system) and the other is a large ( $8.0 \mathrm{~mm}$ in diameter) opaque round blue bead (IIa39). Both bead varieties were the two most common in the 41 HO64 collection documented by Perttula (2004:Table 1), comprising more than 92 percent of the bead sample.

In notes on file at the Texas Archeological Research Laboratory, The University of Texas at Austin, Krieger noted that Caddo ceramic sherds from an Allen phase occupation were abundant in the plowed field. He identified sherds from Bullard Brushed, La Rue Neck Banded, Maydelle Incised, and Patton Engraved vessels at $41 \mathrm{HO} 64$.

\section{$41 \mathrm{HO66}$}

This Nabedache Caddo site was situated along the edge of the second or higher alluvial terrace on the west side of San Pedro Creek (see Figure 9). Site 41HO67 is not far to the southwest.

Krieger collected six pieces of burned animal bone and 51 Caddo ceramic vessel sherds (Table 2). The ceramic sherds are from both grog-tempered (59 percent) and bone-tempered (41 percent). The plain to decorated sherd ratio (P/DR) is a low 0.24, which is consistent with this being an Historic Caddo (Nabedache Caddo) ceramic assemblage on San Pedro Creek. In other known Historic Caddo sites on San Pedro Creek, P/DR ratios range from 0.32-0.60 (Perttula and Nelson 2006, 2007a, 2007b; Perttula et al. 2011).

Table 2. Ceramic vessel sherds collected by Krieger in 1944 from the George A. Moore Site 2 (41HO66).

Ware/sherd type Grog-tempered Bone-tempered

Plain Ware

base sherds

body sherds

4

2

5

5 
Table 2. Ceramic vessel sherds collected by Krieger in 1944 from the George A. Moore Site 2 (41HO66), cont.

\begin{tabular}{lll}
\hline Ware/sherd type & Grog-tempered & Bone-tempered \\
\hline
\end{tabular}

\section{Utility ware}

\section{Brushed}

diagonal brushing marks

horizontal brushing marks

opposed brushing marks

overlapping brushing marks

parallel brushing marks

\section{Brushed-Appliqued}

opposed brushed and appliqued node

\section{Neck Banded}

horizontal neck bands

\section{Pinched}

parallel pinched ridges

\section{Engraved}

sets of vertical engraved lines

Totals

30

1

$-$

1

Fine Ware

Sherds with brushed decorations represent 88 percent of the decorated sherds from the site (see Table 2). In other Nabedache Caddo ceramic assemblages on San Pedro Creek, brushed sherds comprise 69.2-76 percent of all the decorated sherds in the Nabedache Caddo ceramic assemblages (Table 3). If the proportion of brushing increases through time, such that sites with the highest percentage of brushed sherds are the youngest in a group of assemblages, and the P/DR value decreases from older to youngest, then the George A. Moore \#2 site is the youngest of the documented Nabedache Caddo ceramic assemblages (41HO91, 41HO211, 41HO214, and 41HO263, see below and Perttula and Nelson 2006, 2007a, 2007b) on San Pedro Creek.

Table 3. Decorative Methods at San Pedro Creek sites.

Attributes

$41 \mathrm{HO} 263$

0.60

36.4

all sherds
Historic Nabedache Caddo Sites

41HO211

$41 \mathrm{HO} 214$

$41 \mathrm{HO} 91$

0.56

$\begin{array}{ll}0.34 & 0.32\end{array}$

56.7

44.2

53.2

56.7


Table 3. Decorative Methods at San Pedro Creek sites, cont.

\begin{tabular}{|c|c|c|c|c|}
\hline \multirow[t]{2}{*}{ Attributes } & \multicolumn{4}{|c|}{ Historic Nabedache Caddo Sites } \\
\hline & $41 \mathrm{HO} 263$ & $41 \mathrm{HO} 211$ & $41 \mathrm{HO} 214$ & $41 \mathrm{HO} 91$ \\
\hline $\begin{array}{l}\% \text { Brushed among } \\
\text { decorated sherds } \\
\% \text { Engraved among }\end{array}$ & 58.2 & 71.4 & 76.0 & 69.2 \\
\hline all sherds & 4.5 & 10.6 & 7.8 & 9.8 \\
\hline $\begin{array}{l}\% \text { Incised among } \\
\text { all sherds }\end{array}$ & 8.0 & 9.6 & 5.3 & 4.9 \\
\hline $\begin{array}{l}\text { \% Punctated among } \\
\text { all sherds }\end{array}$ & 11.4 & - & 2.6 & 3.3 \\
\hline $\begin{array}{l}\text { \% Neck banded } \\
\text { among all sherds } \\
\% \text { Appliqued } \\
\text { among all sherds }\end{array}$ & 1.1 & 2.2 & - & 2.3 \\
\hline
\end{tabular}

Sample sizes: 41HO263 (33 plain sherds and 55 decorated sherds); 41HO211 (24 plain sherds and 70 decorated sherds); 41HO214 (55 plain sherds and 172 decorated sherds); 41HO91 (22 plain sherds and 39 decorated sherds), see Perttula and Nelson (2006, 2007a) and Perttula et al. (2011).

The only substantial difference between these San Pedro Creek Caddo sites is the absence of Patton Engraved fine ware sherds in the small sample from the George A. Moore site, and its ubiquity at the Historic Nabedache Caddo sites. I take the absence of Patton Engraved at the George A. Moore site to be simply a product of decorated sherd sample size, taking into account the other measurements of very similar decorative methods (see Table 3). For example, 71 percent of all the sherds in the Krieger sample from the George A. Moore site are brushed, and 88 percent of all the decorated sherds are brushed (see Table 3); these proportions are higher than other Nabedache Caddo sites on San Pedro Creek. The very high proportion of brushed sherds in the George A. Moore 2 site ceramics was confirmed in 2010 investigations summarized by Perttula et al. (2011:38), although the ceramic sherd assemblage from this work only comprised 15 sherds.

In addition to the many brushed sherds, likely from Bullard Brushed jars, in the assemblage, one body sherd has opposed brushing marks surrounding a single appliqued node (Figure 10a). Two sherds with parallel pinched ridges are from Killough Pinched vessels, and one body sherd with horizontal neck bands is from a La Rue Neck Banded vessel. The only engraved fine ware sherd in the assemblage is from a grogtempered bottle body sherd. It has at least two sets of three closely-spaced vertical engraved lines that end just above the vessel base (Figure 10b). This sherd may be from either a cylindrical Hume Engraved or Poynor Engraved bottle (see Suhm and Jelks 1962:Plates 42 and 63).

\section{$41 \mathrm{HO67}$}

The George A. Moore 3 site (41HO67) is on the same alluvial terrace as 41HO66 (see Figure 9). Krieger collected a total of six Caddo sherds from the site: one grog-tempered base sherd, a grog-tempered Killough Pinched body sherd, and four grog-tempered brushed rim and body sherds. The one rim, from a Bullard Brushed jar, has horizontal brushing marks, while the body sherds have vertical brushing marks. In the absence of Patton Engraved sherds or European trade goods, this site is most likely an ancestral Nabedache Caddo site that was occupied prior to ca. A.D. 1650. 


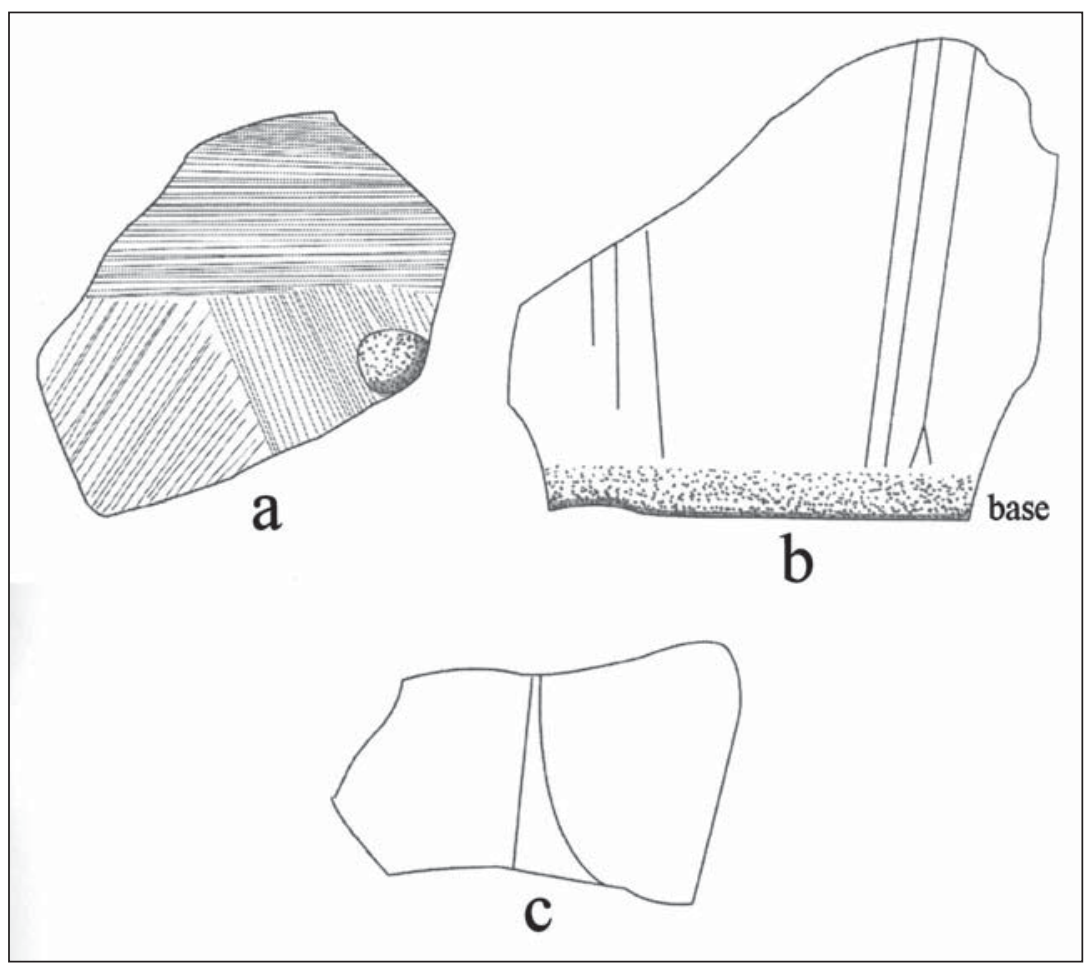

Figure 10. Decorative elements on selected ceramic sherds: a, brushedappliqued body sherd from 41HO66; b, engraved bottle body sherd from $41 \mathrm{HO} 66$; c, cf. Poynor Engraved body sherd from $41 \mathrm{HO} 69$.

\section{$41 \mathrm{HO69}$}

Only a small sample of Caddo ceramic sherds were collected from 41HO69, downstream a short distance from the other sites (see Figure 9), during the 1944 reconnaissance. This includes a grog-tempered parallel brushed body sherd, a plain bone-tempered body sherd, and a bone-tempered Poynor Engraved carinated bowl body sherd (see Figure 10c). This sherd may be from a Poynor Engraved, var. Cook vessel (see Perttula 2011:Figure 6-64c-d). This variety of Poynor Engraved was apparently made from ca. A.D. 1400-1650, but was most common on Caddo sites in the Neches River basin dating between ca. A.D. 1400-1560 (Perttula 2011:Table 6-37). This suggests that 41HO69 is an ancestral Nabedache Caddo site, occupied well before sustained European contact.

\section{SUMMARY AND CONCLUSIONS}

Archaeological work over the years, beginning with Alex Krieger's reconnaissance in 1944, has identified a number of Caddo sites of post-A.D. 1690 age along San Pedro Creek in Houston County, Texas. There are also ancestral Caddo sites along the creek that date prior to European contact, indicating that the lower course of the creek was home to Caddo peoples by ca. A.D. 1400, if not earlier. Archival sources and historic maps of the San Pedro Creek area and East Texas indicate that these Caddo sites are the material remains of Nabedache Caddo habitation sites and cemeteries. In addition to a variety of ceramic vessel sherds and chipped stone artifacts, these sites also contain a wide range of European trade goods that were obtained from Spanish and French traders, colonists, and missionaries.

It is known that the Spanish constructed the first mission in 1690 among the Nabedache Caddo peoples living on San Pedro Creek, Mission San Francisco de los Tejas, but the archaeological remains of the mission 
compound have yet to be found. Historical and archival information indicates that the mission was about 10 miles upstream on San Pedro Creek from its confluence with the Neches River. This would place the mission well upstream from the Nabedache Caddo sites discussed in this article. These sites are nevertheless part of the community the Spanish referred to as San Pedro de los Nabedaches.

I hope that a concerted archaeological and historical/archival research effort can be mounted in the years to come that focuses on the community of San Pedro de los Nabedaches. The purposes of that effort would be to not only locate the 1690-1693 Mission San Francisco de los Tejas on San Pedro Creek, but to also obtain more detailed information on the archaeological character of the associated Nabedache sites and community on the creek.

\section{ACKNOWLEDGMENTS}

I thank Robert S. Weddle for his discussions concerning San Pedro de los Nabedaches and the location of the 1690 Spanish mission on San Pedro Creek, as well as for a copy of his 2012 report on Camino Real de los Tejas. Lance Trask and Sandra Hannum prepared the figures in this article. Finally, Jonathan Jarvis at the Texas Archeological Research Laboratory at The University of Texas at Austin facilitated access to the records and collections from the San Pedro Creek sites.

\section{REFERENCES CITED}

Berlandier, J. L.

1969 The Indians of Texas in 1830. Edited by J. C. Ewers. Smithsonian Institution Press, Washington, D.C.

Bolton, H. E.

1908 The Native Tribes About the East Texas Missions. Quarterly of the Texas State Historical Association 9:249-276.

1987 The Hasinai: Southern Caddoans as seen by the earliest Europeans. University of Oklahoma Press, Norman.

Bruseth, J. E. and N. A. Kenmotsu

1993 From Naguatex to the River Daycao: The Route of the Hernando de Soto Expedition Through Texas. North American Archaeologist 14(2):99-125.

Cooper, J. H. and E. S. Cooper

2005 Archaeological Investigations of 291 Acres at Mission Tejas State Park, Houston County, Texas. Report of Investigations No. 2004-06. C-Dimensions, Plano.

Corbin, J. E.

1991 Retracing the Camino de los Tejas from the Trinity River to Los Adaes: New Insights into East Texas History. In A Texas Legacy: The Old San Antonio Road and the Caminos Reales, a Tricentennial History, 1691-1991, edited by A. J. McGraw, J. W. Clark, and E. A. Robbins, pp. 191-219. Texas State Department of Highways and Public Transportation, Austin.

Cunningham, D. S. (editor)

2006 The Domingo Ramon Diary of the 1716 Expedition into the Province of the Tejas Indians: An Annotated Translation. Southwestern Historical Quarterly 110(1):39-67.

Erickson, E. C. and J. E. Corbin

1996 Archaeological Survey and Cultural Resource Assessment of Mission Tejas State Historical Park, Houston County, Texas. Public Lands Division, Cultural Resource Program, Texas Parks and Wildlife Department, Austin. 
Foster, W. C. (editor)

1998 The La Salle Expedition to Texas: The Journal of Henri Joutel, 1684-1687. Texas State Historical Association, Austin.

Good, C. E.

1982 Analysis of Structures, Burials, and Other Cultural Features. In The Deshazo Site, Nacogdoches County, Texas, Volume 1, edited by D. A. Story, pp. 51-110. Texas Antiquities Permit Series 7. Texas Antiquities Committee, Austin.

Jackson, J.

1999 Shooting the Sun: Cartographic Results of Military Activities in Texas, 1689-1829. 2 Vols. The Book Club of Texas, Lubbock.

Jackson, R. H.

2004 Congregation and Depopulation: Demographic Patterns in the Texas Missions. Journal of South Texas 17(2):7-38

2005 Missions and the Frontiers of Spanish America: A comparative study of the impact of environmental, economic, political, and socio-cultural variations on the missions in the Rio de la Plata region and on the Northern Frontier of New Spain. Pentacle Press, Scottsdale, Arizona.

Kidd, K. E. and M. A. Kidd

1970 A Classification System for Glass Beads for the Use of Field Archaeologists. Occasional Papers in Archaeology and History No. 1, pp. 45-89. National Historic Sites Service, National and Historic Parks Branch, Department of Indian Affairs and Northern Development, Ottawa, Ontario.

McGraw, A. J., J. W. Clark, and E. A. Robbins (editors)

1991 A Texas Legacy: The Old San Antonio Road and the Caminos Reales, a Tricentennial History, 1691-1991. Texas State Department of Highways and Public Transportation, Austin.

Middlebrook, $\mathrm{T}$.

2007 A Survey of Historic Caddo Sites in Nacogdoches County. Journal of Northeast Texas Archaeology 26:99-115.

Neighbours, K. E.

1973 Indian Exodus: Texas Indian Affairs, 1835-1859. Nortex Offset Publications, Quannah.

1975 Robert Simpson Neighbors and the Texas Frontier, 1836-1859. Texian Press, Waco.

Newell, H. P and A. D. Krieger

1949 The George C. Davis Site, Cherokee County, Texas. Memoir No. 5. Society for American Archaeology, Menasha, Wisconsin.

Perttula, T. K.

2011 The Ceramic Artifacts from the Lang Pasture Site (41AN38) and the Place of the Site within an Upper Neches River Basin Caddo Ceramic Tradition. In Archeological Investigations at the Lang Pasture Site (41AN38) in the Upper Neches River Basin of East Texas, assembled and edited by T. K. Perttula, D. B. Kelley, and R. A. Ricklis, pp. 145-320. Archeological Studies Program Report No. 129, Texas Department of Transportation, Environmental Affairs Division, Austin.

Perttula, T. K., with contributions by T. E. Emerson and R. E. Hughes

2004 41HO64/41HO65, Late 17th to Early 18th Century Caddo Sites on San Pedro Creek in Houston County, Texas. Bulletin of the Texas Archeological Society 75:85-103.

Perttula, T. K. and B. Nelson

2006 Test Excavations at Three Caddo Sites at Mission Tejas State Park, Houston County, Texas. Report of Investigations No. 76. Archeological \& Environmental Consultants, LLC, Austin. 
2007a Archeological Investigations in 2007 at Mission Tejas State Park in Houston County, Texas. Report of Investigations No. 85. Archeological \& Environmental Consultants, LLC, Austin.

2007b Place of the Blackberry: Historic Nabedache Caddo Archeology at Mission Tejas State Park, Houston County, Texas. Current Archeology in Texas 9(1):1-11.

Perttula, T. K., B. Nelson, and M. Walters

2011 Archeological Survey Investigations to Identify 17th-early 19th Century Caddo Sites along El Camino Real de los Tejas National Historic Trail in East Texas. Report of Investigations No. 108. Archeological \& Environmental Consultants, LLC, Austin.

Story, D. A. (editor)

1982 The Deshazo Site, Nacogdoches County, Texas, Volume 1. Texas Antiquities Permit Series 7. Texas Antiquities Committee, Austin.

1995 The Deshazo Site, Nacogdoches County, Texas, Volume 2. Studies in Archeology 21. Texas Archeological Research Laboratory, The University of Texas at Austin.

Story, D. A. and D. G. Creel

1982 The Cultural Setting. In The Deshazo Site, Nacogdoches County, Texas, Volume 1, edited by D. A. Story, pp. 20-34. Texas Antiquities Permit Series 7. Texas Antiquities Committee, Austin.

Suhm, D. A. and E. B. Jelks (editors)

1962 Handbook of Texas Archeology: Type Descriptions. Special Publication No. 1, Texas Archeological Society, and Bulletin No. 4, Texas Memorial Museum, Austin. Reprinted in 2009, Gustav's Library, Davenport, Iowa.

Swanton, J. R.

1942 Source Material on the History and Ethnology of the Caddo Indians. Bulletin 132. Bureau of American Ethnology, Smithsonian Institution, Washington, D.C.

Wade, M. F.

2008 Missions, Missionaries, and Native Americans: Long-Term Processes and Daily Practices. University Press of Florida, Gainesville.

Weddle, R. S.

2012 Archival and Archaeological Research: Camino Real de los Tejas and Texas State Parks. Texas Parks and Wildlife Department, Austin.

Williams, J. M.

2007 GIS Aided Archaeological Research of El Camino Real de Los Tejas with Focus on the Landscape and River Crossings along El Camino Carretera. Masters thesis, Stephen F. Austin State University, Nacogdoches.

Woldert, A. E.

1935 The Location of the Tejas Indian Villages (San Pedro) and the Spanish Missions in Houston County. Southwestern Historical Quarterly 38(3):203-212. 